\title{
Novo problema de indexação no Google Acadêmico.
}

Karina Figueira (1)

\section{EDITORIAL}

Nosso corpo Editorial constatou novo probela de indexação dos artigos do BJIHS dentro da base de dados do Google Acadêmico (GA). Como não houve nenhuma manifestação da equipe técnica do GA sobre o ocorrido, entramos com um processo judicial contra o Google para que o mesmo venha em juizo e reponda nossas questões sobre o que esta acontecendo. Mantereemos os leitores do BJIHS informados sobre o assunto na proxima edição, caso haja alguma atualização.

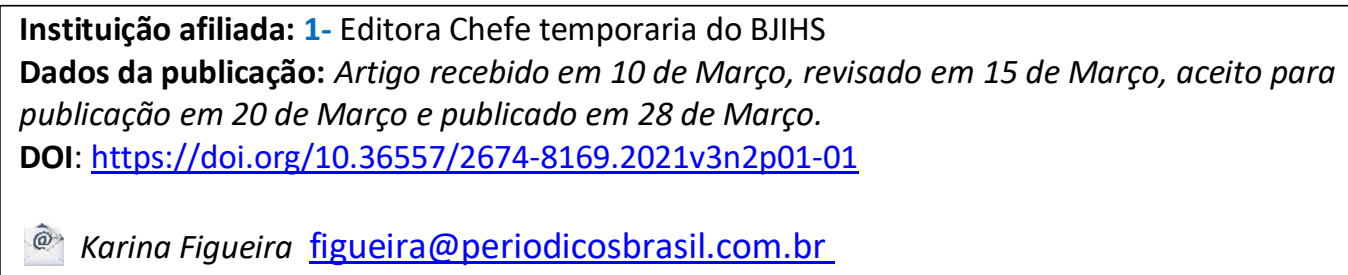

License. 